ment at Sheffield, obtained his Ph.D. there in 1950, and then returned to the Imperial College to join Prof. F. G. Gregory's team in the Research Institute of Plant Physiology. During 1953-54 he held a Rockefeller Foundation research fellowship at Berkeley, where he was closely associated with Prof. W. Z. Hassid. In 1956 ho was appointed to the academic staff of Imperial College as reader in plant physiology and, later, as reader in enzymology. Dr. Edelman's research has been concerned mainly with the enzymatic synthesis of polysaccharides, particularly of fructosans, and he has published many papers on various aspects of this problem. Other publications have dealt with some transformations of sucrose, and with dark-fixation of carbon dioxide in Kalanchoë. More recontly, ho has initiated research into the formation of 'induced' enzymes in mature plant tissues, and has shown that plant hormones (auxins) affect the induction. All plant biochemists will bo interested in the future development of these investigations.

The Rock Carling Fellowship: Prof. W. V. Mayneord

Prof. W. V. MAYNeORd, professor emeritus of physics as applied to medicine, University of London, has been elected the third (1964) Rock Carling Fellow by the Nuffield Provincial Hospitals Trust. The fellowship was founded in 1961 as a memorial to the late Sir Ernest Rock Carling, for many years a Governing Trustee and chairman of the Medical Advisory Panel of the Nuffield Provincial Hospitals Trust. Each holder of the fellowship will seek to review in a monograph the state of knowledge and activity in one of the fields in which Sir Ernest had been particularly interested and which is within the purposes of the Trust. The arrangements provide that the monograph will be introduced by a public lecture given at a medical teaching centre in the United Kingdom. The subject of Prof. Mayneord's review is "Radiation and Health", and this will be introduced at a public lecture at the Medical School, University of Birmingham, on November 19. Admission will be by ticket only, for which applications should be made to the Secretary, Nuffield Provincial Hospitals Trust, 3 Prince Albert Road, London, N.W.1.

\section{Botany in the University of Delhi: Prof. P. Maheshwari}

A SPECIAL volume of the Journal of the Indian Botanical Society has been issued in honour of Prof. P. Maheshwari on oxtoring his sixtieth year (42A. Edited by T. S. Sadasivan. Pp. xxxiv + 330. Madras 5: Indian Botanical Sociøty, University Botany Laboratory, 1963. Rs. 32; 50s.; 7 dollars). Prof. Maheshwari has been professor and head of the department of botany in the University of Delhi since 1949. He is well known for his work on the morphology and embryology of vascular plants and the in vitro culture of reproductive organs. In addition to a complete bibliography of his published works the volume contains 37 invited contributions on mycology and plant pathology, algae, bryophytes, ptoridophytes, angiosperm anatomy, morphology and taxonomy, palynology, embryology, cytology, gonetics, plant breeding, palæobotany and in vitro culture.

\section{India at Mid-passage}

The Overseas Development Institute has collected four short papers discussing aspects of India's third Five Year Plan (India at Midpassage. London: Overseas Development Institute, Ltd., 1964. 6s.). In the first, Mr. W. Clark discusses the progress of the Plan (1961-66), and suggests that it has not received sufficient publicity, nor have the central planners adequately appreciated the immense difficulty of passing on new agricultural techniques to the mass of the populace. Mr. Clark believes that nothing could be more useful than continued private investment in India, but it is essential that the Aid India Consortium should accept responsibility for playing a definite part in the planned attack on poverty or in the plan for economic growth. The success or failure of India's planned effort to end its poverty hangs in the balance, and although the outcome rests in Indian hands the key factor of external assistance can be applied effectively or ineffectively. There is at present great danger that too little aid will be given just too ineffectively. It is therefore essential that the donors should accept in principle the aims and methods of the Indian Plan and judge the amount that is to be made available in terms of what is needed to achieve its objectives. In the second paper, Mr. R. Neild examines population policy in the context of long-term economic planning in India. $\mathrm{He}$ points out that any population policy is unlikely to do more than moderate the growth of the population over the next 10 or 20 years, and stresses the urgent need to expand programmes of family planning as fast as possible and to survey the results obtained so far. There is also the broader question of the priority and attention which should be given to population policy and economic planning. He concludes firmly that if the objective of Indian planning is to raise the living standards, far too little is now spent on population policy. E. F. Schumacher examines the problem of rural industries, including the need for a suitable technology and also for a suitable form of organization. He suggests that detailed design investigations should be undertaken on all industries envisaged for establishment in rural areas. K. B. Lall discusses: Indo-British trade prospects.

\section{Expansion of Higher Education in Britain}

IN a brief debate in the House of Commons on July 29 on scientific and technological education, opened by Dr. J. Bray, Sir Edward Boyle, the Minister of State for Education and Science, reaffirmed the Government's endorsement of the recommendations of the Robbins Report regarding the building up of technological universities and the development of management studies. He thought that the Robbins figure of 45,000 full-time advanced students in technical schools other than the Colleges of Advanced Technology was an underestimate of what would be achieved, and insisted that the Government would plan firmly on the basis of 219,000 students in institutions of university status by $1973-74$, and 390,000 full-time places in higher education in the full ten-year plan. Output of qualified scientists and technologists this year was estimated as 19,500, and in the present year 1,073 awards of Dip.Tech. had been made. Between 1953 and 1968 capital work to the value of $£ 18.5$ million would have been done at the Imperial College of Science and Technology and its numbers would have increased from 1,700 to 3,700. Between 1955 and 1967 the capital expenditure of the Manchester College of Science and Technology would exceed $£ 6.5$ million with an increase in numbers from 800 to 2,700 , while the University of Strathclyde over the same twelve years would have had a capital outlay of $£ 5.25$ million. Between 1955 and 1966 , capital allocations to the University of Durham would total about $£ 5.75$ million, of which a little less than $£ 1$ million would be for applied science; while in the same period capital allocations to the University of Newcastle upon Tyne would total $£ 9$ million, of which $£ 3.7$ million would be for engineering and applied science. Sir Edward Boyle also paid tribute to the contribution of the Sunderland and Rutherford Technical Colleges and of the Constantine College at Middlesbrough to the provision of higher technical education in the North.Fast.

\section{Financing" Education in Britain}

A PAMPHLET recently issued by the National Union of Teachers looks at the system of educational finance in Britain (The Financing of Education: A Discussion Document. Pp. i+38. London: National Union of Teachers, 1964. 28.). It examines suggestions that have 